\title{
The Effect of Push Motivational Factors and Pull Motivational Factors on Tourist Loyalty Through Satisfaction on Halal Tourists in East Java
}

\author{
CHRISTINA ESTI SUSANTI \\ Faculty Of Business \\ Widya Mandala Catholic University Surabaya \\ Jalan Dinoyo 42 - 44, Surabaya \\ INDONESIA
}

\begin{abstract}
Many countries in the world consider tourism as an important sector in their economy. Tourism can bring many people from various countries to a destination and as a result tourism can contribute significantly to the economy. Achieving tourist satisfaction can be very challenging for the country. There are several factors that can affect tourist satisfaction; among them, the motivating and interesting motivational factors tested in this study. In this study examines the influence of these motivational factors on tourist satisfaction. Internal attributes and halal tourism destination attributes are used to measure motivational factors. Nowadays the concept of halal has become a trend in economic development in Indonesia, starting from the emergence of halal products (food and beverages), halal cosmetics, halal fashion and halal tourism to lifestyle (halal lifestyle). Therefore the halal tourism destination (halal tourism) is the object of this study. The results of the study prove that push motivational factors and pull motivational factors have a positive and significant effect on tourist loyalty through satisfaction with halal tourism destinations in East Java.
\end{abstract}

Keywords: Push Motivational Factors, Pull Motivational Factors, Tourist Satisfaction, Tourist Loyalty.

Received: November 30, 2020. Revised: April 23, 2021. Accepted: May 4, 2021. Published: May 12, 2021.

\section{Introduction}

The new segment of the tourism industry used as the object of this research is halal tourism. Nowadays the concept of halal has become a trend in economic development in Indonesia, starting from the emergence of halal products (food and beverages), halal cosmetics, halal fashion and halal tourism to lifestyle (halal lifestyle). All Muslims must only consumed halal-certified products as Islam sets a comprehensive approach in its non-negotiable core [37]. There are 7 economic sectors that have increased significantly, namely: culinary, Islamic finance, insurance industry, fashion, cosmetics, pharmaceuticals, entertainment, and tourism. Where the entire sector carries the concept of halal in each of its products. There are several things that become the motor of the growth of the global Muslim market, namely the demographics of the young and largesized Muslim market, the rapid economic growth of Muslim-majority countries encourages the growth of Islamic business, one of which is halal tourism.

Based on the Global Muslim Travel Index (GMTI) in [1] which is a reference for halal tourism standards in the world, 3 groups of halal tourism criteria and 11 derivative indicators are listed, namely: (1) Family Friendly Destinations (travel destinations must be family friendly, public security for Muslim tourists, the number of muslim tourist arrivals is quite crowded), (2) Services and facilities in muslimfriendly destinations (Food choices and halal guarantee, easy and good access to worship, facilities at the airport which are muslim friendly, As well as adequate accommodation options), (3) Halal awareness and destination marketing (ease of communication, reach and awareness of the needs of Muslim tourists, Air transportation connectivity, as well as visa requirements). To meet these indicators, a halal tourism destination must have a commitment at the stakeholder and community levels, in this case the government.

The purpose of this study was to examine the effect of push motivational factors and pull motivational factors on tourist loyalty through satisfaction with halal tourism destinations in East Java. Where push motivational factors are measured from the internal factors of tourists while pull motivational factors are measured from the attributes of the tourist destination. These variables are raised in this study because to find out how a person's reason / motivation in making a decision on something can affect his satisfaction and loyalty to something that was decided upon.

The theoretical benefits of this research are expected to provide tourism researchers with knowledge about the influence of push motivational factors and pull motivational factors both partially and simultaneously on tourist satisfaction at halal tourism destinations. The empirical benefits of this research in general are contributing strategic thinking to halal tourism businesses to manage tourist satisfaction, especially 
from measurements of push motivational factors and pull motivational factors.

\section{Literature Review \\ 2.1. Prior Research}

The first previous research that was used as a reference for this research was a study conducted by Rahman in 2014 in Malaysia [2]. The purpose of the study is to measure the influence of tourist motivation on Islam tourist satisfaction and loyalty of Islamic tourist destinations. The PLS-based SEM survey instrument technique was used to test the relationships in the proposed model. Primary data collected as many as (n) 198 from various tourist sites in Kuala Lumpur were carried out to examine the relationship between exogenous and endogenous constructs expressed in the proposed structural model. The research findings reveal Islamic attributes and service quality have a significant relationship with satisfaction and loyalty of Islamic tourism destinations, while destination attributes are not significant. Nevertheless, overall satisfaction of Islamic tourists has a significant influence on destination loyalty. Regarding tourist perceptions about Islamic tourism destinations, the results of this study contribute to the understanding that tourists show satisfaction with Islamic tourism in Malaysia as their choice and Islamic tourism destinations are recommended in various aspects.

The second previous study that was used as a reference for this research was a study conducted by Abror et al., 2018 in West Sumatra [3]. The study analyzed the influence of the halal tourism dimension (ie, Islamic facilities, Halal, Islamic culture, and free from alcoholic drinks and gambling) on tourist satisfaction in West Sumatra. This research is a causative study which examines the influence of Islamic facilities, Halal, Islamic culture, free of alcoholic drinks and gambling of tourist satisfaction. The respondents of this study are domestic and foreign tourists who have visited West Sumatra. This study uses a purposive sampling technique for data collection. Multiple linear regression was performed to analyze the data. The results show that all dimensions of halal tourism, Islamic facilities, Halal, Islamic culture, and free from alcoholic drinks and gambling have a positive impact and a significant impact on tourist satisfaction in West Sumatra.

\subsection{Theoretical Basis}

\subsubsection{Halal Tourism}

Halal tourism is any tourism object or action that is permitted according to Islamic teachings to be used or involved by Muslims in the tourism industry. The definition considers Islamic law (sharia) as the basis for delivering tourism products and services to the target customers who are mostly Muslim, such as halal hotels (according to sharia hotels), halal resorts, halal restaurants, and halal travel. The definition claims that the location of activities is not limited to the Muslim world. Therefore, this includes services and products designed for Muslim travelers in Muslim and non-Muslim countries. Furthermore, the definition considers the purpose of traveling is not necessarily religious but may be one of the general motivations of tourism [4].

The Muslim tourism market continues to grow at a faster rate than the overall global tourism industry. Despite its status as the most important consumer segment in the global tourism industry, the potential for the Muslim travel market is not yet full. At present, Muslim travelers are still relatively underserved due to factors such as lack of awareness among tourism authorities and service providers as well as poor understanding of the specific needs and preferences of this demographic. This is manifested in the lack of facilities and experience that meets the needs of Muslim travelers, as well as scarce or inconsistent information about existing Muslimfriendly facilities.

In the service industry, staff awareness and training is very important in ensuring that Muslim travelers can fully feel the facilities and flexibility that are introduced to serve for their preferences. Rigorous training is very important for personnel working in food preparation, bearing in mind the need to understand the various requirements governing halal and haram concoctions. It should be noted that service personnel in hotels, restaurants and other public spaces must be familiar with the general requirements of Muslim tourists such as the location of prayer facilities and halal food without having to impose it on them. Offering meal service times to coincide with the dawn and breaking fast during Ramadan or prayer scheduling during tour schedules are examples of how the industry can go the extra mile for Muslim customers.

\subsubsection{Push Motivational Factors}

Push motivational factors are factors that motivate or create intangible or intrinsic desires from individual travelers to go on vacation [5], [6]. According to [5], the driving factor consists of 7 social-psychological motives (escape, self-exploration, relaxation, prestige, increased kinship, and social interaction) and 2 cultural motives (novelty and education). These driving factors are recognized as a first step and a 
useful tool in explaining the desire to travel and understanding tourist behavior [5].

Iso-Ahola [7] describes the driving factors as mental preparation for human activities and is related to the optimal level of arousal of individuals. Some of the common driving factors found in many studies are escape from the routine of daily life, relaxation, exploration, social interaction, increased relations and prestige [8]. A study of the motivations of Danish travelers [8] found that Danish travelers felt social relations with family and friends as the most important motive for travel, followed by escape / relaxation, respect for natural resources, exploration, respect for sites and famous heritage, and prestige and impression. However, the motives with the lowest average scores are prestige and impression.

A study of Japanese tourists' motivations and expected benefits from a trip to England [9] revealed that they traveled to find new or unusual experiences, different cultures, and refresh or escape from everyday life. To get a broader view of understanding or feeling younger values is also common in Japan, while looking for novelty it is important for Japanese people both older and younger. The decision to take a vacation is based on time and cost.

In the study of the motivation and perception of Indian tourists traveling to Bangkok, revealed the driving factors consisting of having fun, seeing and experiencing new destinations, doing something interesting, reducing stress, getting out of work routines, and living and learning new things. While British and Australian tourists travel to Thailand based on their interest in foreign land [10].

\subsubsection{Pull Motivational Factors}

Pull motivational factors, on the other hand, are resources and real perceptions and expectations of tourists towards certain features, attractions, or attributes. Therefore, it plays an important role in the choice of tourist destinations once the decision to travel has been made [5], [6], [8]. Attractor factors are external forces related to nature and historic tourist attractions, food, people, recreational facilities, and images of marketed destinations [6].

Swarbrooke and Horner [12] emphasize the importance of various motivators related to consumers in the tourism industry, which can be categorized as those who motivate someone to take a vacation and those who motivate someone to take a particular vacation to a specific destination. It is important for tourism marketers to investigate not only why individuals travel and what they want to do while on vacation in relation to their internal drives but also on their motives related to tourist destinations [13]. Pull motivational factors become important and require consideration in terms of attracting new and returning tourists on an ongoing basis. This is especially true in an era where there is both higher competitiveness in the industry itself, and various internal and external constraints that can limit the affordability and demands of individual travel.

Neumann and Reichel [14] stated that travel motivation refers to a set of needs that causes a person to participate in tourism activities. This statement reflects the definition of travel motivation that initiates activities to participate or be employed in the context of exchange of experiences. Tourism experience, as Kozak and Decrop stated [6], "is subjective, based on sensation, involves participation in activities, and results in learning or knowledge acquisition". In addition, as stated by Ahmed that tourism products are "produced and consumed at the time" so the performance of the experience is very important for which tourists will be satisfied with the experience [8]. Nowadays tourists increasingly build their experiences based on the consumption of products and services during their trip, both while traveling and at destinations. In this way, they create a new form of holiday experience, as suggested by Buhalis [17]. This means that tourists also have their role in shaping their own travel experiences.

Beerli and Martin illustrate that one factor related to personal experience is the intensity of visits or the extent of interaction or involvement of individuals with the place [18]. In this case, this study aims to examine the push motivational factors and pull motivational factors on the satisfaction and loyalty of tourists to halal tourism destinations as their destination choices.

\subsubsection{Tourist Satisfaction}

Different from other business activities, tourism is a business selling unforgettable experiences. Tourist satisfaction is "the level of pleasure or overall satisfaction felt by visitors, resulting from the ability of the travel experience to meet the desires, expectations and needs of visitors with respect to travel" [19]. This is a mental evaluation and comparison between what customers expect to receive and what they actually receive [16]. Specifically, tourist satisfaction is based on comparison of pre-trip expectations and images about their destinations and post-trip experiences at this destination [20], [21], [22]. While destination expectations are shaped by past visitors' experiences, friends and family recommendations, tourist information and destination marketers' promises, real 
tourists' experiences are based on what they see, feel, and achieve in tourist destinations [23]. Based on the theory of expectation - disconfirmation [24], if the actual performance is better than customer expectations, this leads to positive disconfirmation and high satisfaction; on the other hand, if actual performance is worse than their expectation, this causes negative disconfirmation and dissatisfaction.

Many previous studies provide empirical evidence in a significant relationship between tourist satisfaction and their intention to revisit and recommend destinations to other potential customers [25], [26], [27], [28]. Tourist satisfaction is considered one of the main variables to maintain competitive business in the tourism industry because it influences the choice of destination, consumption of products and services [25]. Tourist satisfaction has been one of the main areas of tourism research for more than 4 decades.

Tourist satisfaction is measured by the satisfaction of general satisfaction attributes (eg attractions, accommodation, accessibility, facilities and activities) and meeting expectations. The attributes of satisfaction include attractions, lodging, dining, shopping, accessibility, activities and events and the environment [29]. Attributes such as perceived attractiveness, perceived quality, perceived risk and perceived value are used to measure tourist satisfaction [30]. Attributes like the comfort of facilities, safety $\&$ infrastructure, culture of tourist attractions \& shopping, tourist attractions \& atmosphere as well as variety $\&$ accessibility affect tourist satisfaction [31].

\subsubsection{Tourist Loyalty}

Loyalty in the tourism sector has been studied but there are still many questions that stand out about how to make these loyal customers in the long run. Tourism has seen relationship marketing techniques and has indeed become an industry pioneer that has been adopted. However, the concept of tourist destination loyalty is only found in the literature [32], [23]. Today's tourist destinations face the toughest competition in decades and it may occur even harder in the coming years so marketing managers need to understand the reasons tourists are loyal to the destination and what determines their loyalty [33]. One might ask whether certain tourist destinations can produce loyalty to those who visit them. In this case [34] rgue that "some tourism motivation will hinder destination loyalty", such as, the desire to break up with monotonous daily life, engage with new people, places and cultures or look for new experiences. However, to avoid risk, tourists may feel the need to re-visit a familiar destination.

Barroso found four groups of tourists, based on the need for changes that tourists have when it comes to travel [35]. These groups show significant differences depending on the intention of the tourists to return or recommend the destination. Riley note that the literature on loyalty shows problems in conceptualization, to be solved by empirical means or operational definitions, depending on the research objectives [36].

Yoon \& Uysal notes that destinations can be considered as products and tourists can visit them again or recommend them to other potential tourists like friends or family [23]. Chen \& Gursoy defines goal loyalty operationally as a level of tourist perception about a destination as a good place, one of which they would recommend to others, noting that studies that only consider repeat visits as an indicator of loyalty to destination are lacking [22]. This is because those who do not return to a particular destination may find a different travel experience in a new place, while maintaining loyalty to the destination previously visited. Therefore they emphasize that tourism researchers must use appropriate variables to evaluate tourist loyalty to certain tourism products.

\subsubsection{Research Model}

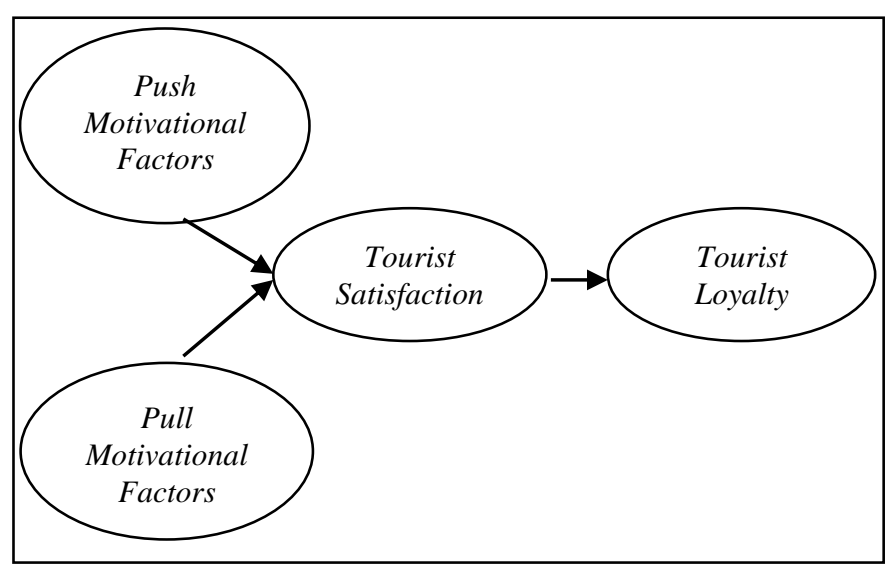

Figure 1. Research Model

Based on the research model, the research hypothesis proposed is as follows::

1. Push motivational factors significantly influence tourist satisfaction with halal tourism destinations in East Java.

2. Pull motivational factors significantly influence tourist satisfaction with halal tourism destinations in East Java. 
3. Tourist satisfaction has a significant effect on tourist loyalty to halal tourism destinations in East Java.

4. Push motivational factors significantly influence tourist loyalty through satisfaction with halal tourism destinations in East Java.

5. Pull motivational factors significantly influence tourist loyalty through satisfaction with halal tourism destinations in East Java.

\section{Research Methods}

This type of research is survey research. This study consisted of 1 exogenous variable and 3 endogenous variables: (1). Exogenous Variables (X): Push Motivational Factors $\left(\mathrm{X}_{1}\right)$ and Pull Motivational Factors $\left(\mathrm{X}_{2}\right)$. (2). Intervening Variables $(\mathrm{Y})$ : Tourist Satisfaction $\left(\mathrm{Y}_{1}\right)$. (3). Endogenous Variables $(\mathrm{Y})$ : Tourist Loyalty $\left(\mathrm{Y}_{2}\right)$.

This study uses a quantitative approach by testing hypotheses. The data measurement tool used was a Likert Scale, giving scores for each category, namely (Budiaji, 2013): strongly agree (score 5), agree (score 4), neutral (score 3), disagree (score 2), and strongly disagree (score 1).

In this study, the study population refers to all visitors of halal tourism destinations in East Java, so a sample of 200 people was taken for this study. According to https://www.cheria-travel.com the halal tourist destination in East Java that became the pilot project is Santen Island Beach in Banyuwangi. Therefore, the study population was all visitors to Santen Island in Banyuwangi. Sampling is carried out using nonprobability sampling techniques that provide equal opportunity or opportunity for each element or member of the population to be selected as a sample ". Sample Characteristics: (1) Tourists who visit Santen Island Beach as a halal tourist destination in East Java. (2) Minimum age 21 years.

The data analysis technique used in this study is the Structural Equation Model (SEM). In SEM, the measurement model, overall model, and structural model are tested. In addition, this research also uses path analysis to explain the relationship between existing variables. By using this SEM method a comprehensive model can be displayed and can explain the relationship between the constructs with each other.

\section{Results}

\subsection{Research Object}

Santen Island Beach is located in Karangharjo Village, south of the old Banyuwangi Station. Santen
Island beach is in the waters of the Bali Strait. Santen Island Beach is also in a strategic location. That was caused by its location facing the island of Bali. Named Santen Island Beach because in it there are many overgrown trees known by the Banyuwangi people with the name Santen trees. To get to the tour the road infrastructure is good, cars, motorbikes and buses can reach, local transportation such as motorcycle taxis and rickshaws are also ready to take tourists to tourist attractions which are only about three kilometers from the heart of the Gandrung City.

\subsection{Validity, Reliability, and Normality Test}

Validity test results show that all measurements have a t-value $>|1.96|$. Reliability test shows that overall the research variables meet the standard values Construct Reliability $(\mathrm{CR})>0.7$. The normality test in this study are multivariate normally distributed. This is shown in the Skewness and Kurtosis section which is on a $5 \%$ scale (>0.05), which means normal multivariate data. Thus it can be concluded that the analysis can be continued.

\subsection{Fit Model Testing}

Table 1. Fit Model Testing

\begin{tabular}{cccc}
$\begin{array}{c}\text { Testing } \\
\text { Model }\end{array}$ & Value & $\begin{array}{c}\text { Cut of } \\
\text { Value }\end{array}$ & Description \\
\hline GFI & 0.89 & $\geq 0.9$ & Good Fit \\
AGFI & 0.85 & $\geq 0.9$ & Good Fit \\
NFI & 0.97 & $\geq 0.9$ & Good Fit \\
IFI & 0.98 & $\geq 0.9$ & Good Fit \\
CFI & 0.93 & $\geq 0.9$ & Good Fit \\
RFI & 0.92 & $\geq 0.9$ & Good Fit \\
RMSEA & 0.03 & $<0.08$ & Close fit
\end{tabular}

Source: Data, processed

Based on Table 1, it can be explained that the research model proposed in this study is acceptable. The research model can be used to predict the effect of each independent variable on the dependent variable.

\subsection{Hypothesis Testing}

Based on Table 2 it can be explained that:

1. The loading factor value of the influence of Push Motivational Factors on Tourist Satisfaction is 0.77 with a tvalue value of 2.23 (> 1.96) so it can be stated that Push Motivational Factors have a positive and significant effect on Tourist Satisfaction. 
2. The loading factor value of the influence of Pull Motivational Factors on Tourist Satisfaction is 0.73 with a tvalue value of 2.59 (> 1.96) so it can be stated that Pull Motivational Factors have a positive and significant effect on Tourist Satisfaction.

3. The loading factor value of the influence of Tourist Satisfaction on Tourist Loyalty is 0.85 with a tvalue value of 3.63 (> 1.96) so it can be stated that Tourist Satisfaction has a positive and significant effect on Tourist Loyalty.

4. The loading factor value of the influence of Push Motivational Factors on Tourist Loyalty through Tourist Satisfaction is 0.98 with a tvalue value of 5.32 (> 1.96) so it can be stated that Push Motivational Factors have a positive and significant effect on Tourist Loyalty through Tourist Satisfaction.

5. The loading factor value of the influence of Pull Motivational Factors on Tourist Loyalty through Tourist Satisfaction is 0.87 with a tvalue of $2.71(>1.96)$ so that it can be stated that Pull Motivational Factors have a positive and significant effect on Tourist Loyalty through Tourist Satisfaction.

Table 2. Hypothesis Test Results

$\begin{array}{ccccc}\begin{array}{c}\text { Hypo- } \\ \text { thesis }\end{array} & \begin{array}{c}\text { Pattern of } \\ \text { Relationship }\end{array} & \begin{array}{c}\text { Load- } \\ \text { ing } \\ \text { Factor }\end{array} & \begin{array}{c}\text { t- } \\ \text { value }\end{array} & \begin{array}{c}\text { Descrip- } \\ \text { tion }\end{array} \\ & & & \end{array}$

$\begin{array}{lccc}\text { Push } & 0.87 & 2.78 & \begin{array}{c}\text { Significan } \\ \text { motivational }\end{array} \\ \text { Factors } & & & \mathrm{t}\end{array}$

Tourist

Satisfaction

2 Pull

0.73

2.45

Motivational

Factors

$\rightarrow$

Tourist

Satisfaction

3 Tourist

Satisfaction

$\rightarrow$

Tourist

Loyalty

4

Push

Motivational

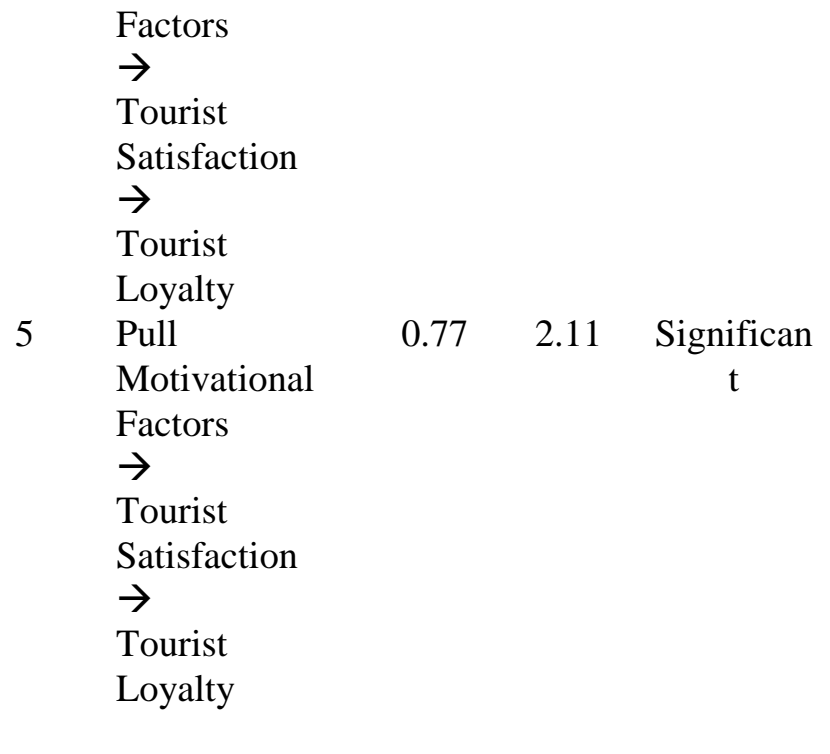

Source: Data, processed

\section{Discussion}

Push Motivational Factors in the descriptive statistical test in this study has a mean value of 3.81 with a standard deviation of 0.76 . The average value proves that respondents agree with the measurement of Push Motivational Factors, namely: Experience life style, Achievement, Escape, Knowledge, Family Togetherness, Adventure, and Prestige. These measurements which have the highest mean value are Prestige with a mean value of 3.97 and a standard deviation of 0.57 and those that have the lowest mean value are Achievements with a mean value of 3.64 and a standard deviation of 0.83 .

Pull Motivational Factors in descriptive statistical tests in this study have a mean value of 3.75 with a standard deviation of 0.92 . The average value proves that respondents agree with Pull Motivational Factors measurements, namely: Cleanliness, Natural Scenery, and Accommodation. These measurements that have the highest mean value are Cleanliness with a mean value of 3.87 and a standard deviation of 0.87 and those that have the lowest mean value are Natural Scenery with a mean value of 3.67 and a standard deviation of 0.76 .

Tourist Satisfaction in descriptive statistical tests in this study has a mean value of 3.75 with a standard deviation of 0.85 . The average value proves that respondents agreed with the measurement of Tourist Satisfaction, namely: having fun with a travel companion, compared to my last visit to another destination I stayed longer on my current visit, fulfilling my dream of visiting a foreign place, and satisfying my desire to be at another place. Those measurements that have the highest mean value are 
having fun with a traveling companion with a mean value of 3.90 and a standard deviation of 0.89 and those with the lowest mean are fulfilling the dream of visiting a foreign place with a mean value of 3.67 and a standard deviation of 0.76 .

Tourist Loyalty in the descriptive statistical test in this study has a mean value of 3.75 with a standard deviation of 0.81 . The average value proves that respondents agree with Tourist Loyalty measurements, namely: Willing to return, Willing to recommend, Have a wonderful image, Feel very loyal, and Always return to the same destinations that previously visited. Those measurements that have the highest mean value are Have wonderful image with a mean value of 4.00 and a standard deviation of 0.88 and those with the lowest mean are Always return to the same destinations that previously visited with a mean value of 3.67 and a standard deviation of 0.76 . Hypothesis test results prove that the influence of Push Motivational Factors on Tourist Satisfaction has a loading factor value of 0.77 with a $t$-value of 2.23 (> 1.96). These results prove that in this study Push Motivational Factors, measured through: Experience life style, Achievement, Escape, Knowledge, Family Togetherness, Adventure, and Prestige have a positive and significant effect on Tourist Satisfaction, as measured through: having fun with a travel companion, compared to my last visit to another destination, I stayed longer on my current visit, fulfilling the dream of visiting a foreign place, and fulfilling the desire to be somewhere else. The first hypothesis which states: Push motivational factors significantly influence tourist satisfaction with halal tourism destinations in East Java, is accepted.

Hypothesis test results prove that the influence of Pull Motivational Factors on Tourist Satisfaction has a loading factor value of 0.73 with a t-value of 2.59 (> 1.96). These results prove that in this study Pull Motivational Factors, which are measured through: Cleanliness, Natural Scenery, and Accommodation have a positive and significant effect on Tourist Satisfaction, as measured through: having fun with a travel companion, compared to my last visit to my other destinations stay longer on the current visit, fulfill the dream of visiting a strange place, and satisfy the desire to be elsewhere. The second hypothesis which states: Pull motivational factors significantly influence tourist satisfaction with halal tourism destinations in East Java, is accepted.

Hypothesis test results prove that the influence of Tourist Satisfaction on Tourist Loyalty has a loading factor value of 0.85 with a t-value of 3.63 (> 1.96). These results prove that in this study Tourist Satisfaction, as measured by: having fun with a travel companion, compared to my last visit to another destination I stayed longer on my current visit, fulfilling my dream of visiting a foreign place, and satisfying my desire to be at a place others, a positive and significant effect on Tourist Loyalty, as measured through: Willing to return, Willing to recommend, Have a wonderful image, Feel very loyal, and Always return to the same destinations that previously visited - The third hypothesis which states: Tourist satisfaction has a significant effect on tourist loyalty to halal tourism destinations in East Java, is accepted. The results of hypothesis testing prove that Push Motivational Factors have a positive and significant effect on Tourist Loyalty through Tourist Satisfaction with a loading factor of 0.98 and a t-value of 5.32 with a cut-off of 1.96. This means that Push Motivational Factors of Santen Island Beach visitors positively and significantly influence Tourist Satisfaction, which in turn affects the Loyalty Tourist at Santen Island Beach. The fourth hypothesis which states: Push motivational factors significantly influence tourist loyalty through satisfaction with halal tourism destinations in East Java, is accepted.

The results of hypothesis testing prove that Pull Motivational Factors have a positive and significant effect on Tourist Loyalty through Tourist Satisfaction with a loading factor of 0.87 and a t-value of 2.71 with a cut-off of 1.96. This means that the Pull Motivational Factors of Santen Island Beach visitors positively and significantly influence the Tourist Satisfaction which ultimately affects the Tourist Loyalty at Santen Island Beach. The fifth hypothesis which states: Pull motivational factors significantly influence tourist loyalty through satisfaction with halal tourism destinations in East Java, is accepted.

The results of this study support previous research conducted by Rahman in 2014 in Malaysia which proves that Islamic attributes and service quality have a significant relationship with satisfaction and loyalty of Islamic tourism destinations. The results of this study also support previous research conducted by Abror et al., 2018 in West Sumatra.

\section{Conclusions and suggestions \\ 6.1. Conclusions}

As stated by Fitrianto [39] that with a large Muslim population, the potential for Indonesian halal tourism is wide open. Countries with a majority of Muslim population make halal tourism a destination such as Middle Eastern countries, Malaysia and Indonesia. With halal tourism, tourists will feel comfortable and 
calm when eating, drinking and worshiping. Opportunities like this should be developed by Indonesia to boost the visits of foreign tourists who are Muslim.

Halal tourism cannot stand alone, but must synergize with all parties who are part of the entire halal industry, including the financial and financing sectors. Therefore, cooperation is needed to encourage the development of halal tourism. With the development of halal tourism, it is hoped that it can encourage the economy of the people and the country to be better. People will earn income with various jobs and sales / rental around tourist attractions, the state will earn foreign exchange as an income of state wealth. Thus the economic growth of the people and the country will increase. The development of halal tourism must be supported by all parties, the government and the people must work together to develop the potential for halal tourism which has bright prospects in the future. Current technology is increasingly developing. Technology cannot be separated as a key factor in the development of halal tourism in Indonesia. Technology has a very important role for the promotion of halal tourism in Indonesia. Access to social media, purchasing systems and online transactions will help make it easier for tourists to access various information needed.

Information technology has a strong impact on tourism trends by creating, distributing and informing about tourism products. Competitiveness is no longer a local issue, so most companies operate in a global competitive environment. World economy is showing intense changes, so it is becoming increasingly difficult to penetrate the world market without strong links with multinational companies and regional economic integrations [38].

The object of halal tourism does not have to be places or Islamic cultural treasures, but can be anything that is interesting as long as it does not violate the provisions of the sharia. Beaches, mountains, caves, toys, and even local culture can be this tourist destination. Indonesia is very rich with attractive destinations and has been known internationally. Therefore, natural attractions that have been undermaintained and neglected must be a priority to be maintained, cared for and beautified and maintain and must be carried out continuously, to be able to create a continuous tourism activity, likewise culture is one of the tourist attractions that become a tourist destination for visiting halal tourist destinations.

\subsection{Suggestions}

\section{Academic Suggestions}

Academic suggestions submitted for future research on the influence of Push motivational factors and Pull Motivational Factors on Tourist Loyalty through Tourist Satisfaction are suggested to be tested on different objects to test the strength of these theories.

\section{Practical Suggestions}

1. Push Motivational Factors

Santen Island Beach Managers should pay attention to the Experience life style, Achievement, Escape, Knowledge, Family Togetherness, Adventure, and Prestige that tourists feel. Therefore, the management of Santen Island Beach must be able to continuously innovate the selling power of Santen Island Beach so that tourists who come always get something new.

2. Pull Motivational Factors

Santen Island Beach Managers should pay attention to Cleanliness, Natural Scenery, and Accommodation provided. The image that the Santen Island Beach is clean, its ecology is still very awake, and provides ample space for a vacation, must be strictly guarded by the management of the Santen Island Beach.

\section{ACKNOWLEDGEMENT}

Thank you very much to:

1. Dean of the Faculty of Business - Widya Mandala Surabaya Catholic University.

2. LPPM Faculty Grant Selection Committee for Research and Community Service Institute Widya Mandala Surabaya Catholic University.

which has facilitated up to this research and dissemination can be carried out very well.

\section{References}

[1] https://www.kompasiana.com, downloaded March 11, 2019.

[2] Rahman. Muhammad Khalilur, Motivating Factors of Islamic Tourist's Destination Loyalty: An Empirical Investigation In Malaysia, Journal of Tourism and Hospitality Management, June, Vol. 2, No. 1, 63 - 77, 2014.

[3] Abror. Abror, Yollanda. Yollanda, and Yunia. Wardi, The Influence of Islamic Tourism on Word of Mouth about Tourism in West Sumatra, Advances in Economics, Business and Management Research, volume 57, 359$365,2018$. 
[4] Battour. M., \& Ismail. M. N, Halal tourism: Concepts, practises, challenges and future, Tourism Management Perspectives, 19(B), 150-154. https://doi.org/10.1016/j.tmp.2015.12.008, 2016.

[5] Crompton. J, Motivations for Pleasure Vacations, Annals of Tourism Research, vol. 6, no. 4, $408-424,1979$.

[6] M. Uysal and C. Jurowski, An Empirical Testing Of The Push And Pull Factors Of Tourist Motivations, Annals of Tourism Research, vol. 21 , no. 4, $844-846,1993$.

[7] Qiao. N, Chen. Y. Guan, and S. Kim, Study On Chinese Tourists' Motivation And Satisfaction To Visit South Korea, International Journal of Tourism Sciences, vol. 8, no. 1, $17-38,2008$.

[8] Kim. E. Suh, and H. Hwang, A Model For Evaluating The Effectiveness Of CRM Using The Balanced Scorecard, Journal of Interactive Marketing, vol. 17, no. 2, 27 - 28, 2003.

[9] Lee. S. Jeon, and D. Kim, The Impact Of Tour Quality And Tourist Satisfaction On Tourist Loyalty: The Case Of Chinese Tourists In Korea, Tourism Management, vol. 32, 1115 1124, 2011.

[10] Tang, Travel Motivation, Destination Image and Visitor Satisfaction Of International Tourists After The 2008 Wenchuan Earthquake: A Structural Modelling Approach, Asia Pacific Journal of Tourism Research, 2013.

[11] Uysal and L. Hagan, Motivations For Pleasure Travel And Tourism, Encyclopedia of Hospitality and Tourism, New York: Van Nostrand Reinhold, 798 - 810, 1993.

[12] Pratminingsih. C, L. Rudatin, and T. Rimenta, Roles Of Motivation And Destination Image In Predicting Tourist Revisit Intention: A Case Of Bandung - Indonesia, International Journal of Innovation, Management and Technology, vol. 5, no. 1, 19-24, 2014.

[13] Pizam. A, Creating Memorable Experiences, International Journal of Hospitality Management, 29(3), 343, 2010.

[14] Dann. Graham, Tourist Motivation: An Appraisal, Annals of Tourism Research, vol. 8, no. 2, 187-219, 1981.

[15] Uysal and C. Jurowski, An Empirical Testing Of The Push And Pull Factors Of Tourist Motivations, Annals of Tourism Research, vol. 21, no. $4,844-846,1993$.
[16] Kim. E. Suh and H. Hwang, A Model For Evaluating The Effectiveness Of CRM Using The Balanced Scorecard, Journal of Interactive Marketing, vol. 17, no. 2, 27 - 28, 2003.

[17] Gnoth, Tourism Motivation And Expectation Formation, Annals of Tourism Research, vol. 24, no. 2, 283 - 304, 1997.

[18] You. J. O'Leary, A. Morrison, and G. Hong, A Cross-Cultural Comparison Of Travel Push And Pull Factors: United Kingdom Vs. Japan, International Journal of Hospitality \& Tourism Administration, vol. 1, no. 2, 1 - 26, 2000.

[19] Chen and D. Tsai, How Destination Image and Evaluative Factors Affect Behavioral Intentions?, Tourism Management, vol 28, no 4, 1115-1122, 2007.

[20] Chon, Understanding Recreational Travelers' Motivation, Attitude And Satisfaction, The Tourist Review, vol. 44, no. 1, 3-7, 1989.

[21] McDowall, International Tourist Satisfaction and Destination Loyalty: Bangkok, Thailand, Asia Pacific Journal of Tourism Research, vol. 15, no. 1, $21-42,2010$.

[22] Chen and F. Chen, Experience Quality, Perceived Value, Satisfaction And Behavioral Intentions For Heritage Tourists, Tourism Management, vol 31, no 1, 29 - 35, 2010.

[23] Yoon. Y \& Uysal. M, An Examination Of The Effects Of Motivation And Satisfaction On Destination Loyalty: A Structural Model, Tour Manage 26 (1) : 45 - 56, 2005.

[24] Oliver. R. L, A Cognitive Model Of The Antecedents And Consequences Of Satisfaction Decisions, Journal of Marketing Research, vol. 17, no. 4, 460-469, 1980.

[25] Kozak \& M. Rimmington, Tourist Satisfaction With Mallorca, Spain, As An Off-Season Holiday Destination, Journal of Travel Research, vol. 38, no. 3, 260-269, 2000.

[26] Valle. do O. P, J. A. Silva, J. Mendes, and M. Guerreiro. Tourist satisfaction and destination loyalty intention: A Structural and categorical analysis, International Journal of Business Science and Applied Management, vol. 1, no. 1, 25-44, 2006.

[27] Wang. J. Zhang, C. Gu, and F. Zhen, Examining Antecedents And Consequences Of Tourist Satisfaction: A Structural Modeling Approach, Tsinghua Science and Technology, vol. 14, no. 3, 397 - 406, 2009. 
[28] Supitchayangkool, The Differences between Satisfied/Dissatisfied Tourists Towards Service Quality and Revisiting Pattaya, Thailand, International Journal of Business and Management, vol. 7, no. 6, $30-39$, 2012.

[29] Chi. C, G.Qing, \& Qu. H, Examining The Structural Relationships Of Destination Image, Tourist Satisfaction And Destination Loyalty: An Integrated Approach, Journal of Tourism Management, 29 : 624 - 636, 2008.

[30] Quintal, Vanessa and Phau. Ian, A Structural Approach towards Perceptions and Satisfaction of Revisit Intentions", in Spanjaard, D. and Denize, S. and Sharma, N. (ed), Proceedings of Australian and New Zealand Marketing Academy Conference, Dec 1 2008, Olympic Park, Sydney: University of Western Sydney, 2008.

[31] Prayag. G, Tourists' Evaluations Of Destination Image, Satisfaction, And Future Behavioral Intentions - The Case Of Mauritius, Journal of Travel \& Tourism Marketing, 26 (8) : 836 $-853,2009$.

[32] Fyall. A, Callod. C, Edwards. B, Relationship Marketing, The Challenge For Destinations, Ann Tour Res, 30 (3) : 644 - 659, 2003.

[33] Chen. J. S \& Gursoy. D, An Investigation Of Tourists' Destination Loyalty And Preferences, Int $J$ Contemp Hospitality Manage, 13(2) : 79 - 85, 2001.

[34] Alegre. J \& Juaneda. C, Destination Loyalty: Costumers' Economic Behaviour, Ann Tourism, Res, 33(3) : 684 - 706, 2006.

[35] Barroso. C, Martı'n E, Martı'n D. The Influence Of Market Heterogeneity On The Relationship Between A Destination's Image And Tourists' Future Behaviour. Tour Manage, 28 (1) : 175 - 187, 2007.

[36] Riley. M, Niininen. O, Szivas. E, Willis. T, The Case For Process Approaches In Loyalty Research In Tourism, Int J Tour Res 3 (1) : $23-32,2001$.

[37] Izwan Harith Md. Ithnan, Ahmad Azmi M. Ariffin, Behavioral Intention Towards "Halal Hotels": Religiosity or Ethnicity?, WSEAS Transactions on Business and Economics, Volume 17, 58-74, 2020.

[38] Iris Mihajlović, Structural Changes in Tourism Market that Highlight the Product Specialization of Travel Intermediaries, WSEAS Transactions on Business and Economics, Volume 17, 608-626, 2020.
[39] Fitrianto, Pengembangan Ekonomi Indonesia Berbasis Wisata Halal, Jurnal Bisnis dan Manajemen Islam, Volume 7, Nomor 1, 69 79, 2019.

\section{Creative Commons Attribution License 4.0 (Attribution 4.0 International, CC BY 4.0)}

This article is published under the terms of the Creative Commons Attribution License 4.0

https://creativecommons.org/licenses/by/4.0/deed.en_US 